\title{
Analysis of Refugee Employment Clause in International Investment Agreements
}

\author{
Qiushi Qu ${ }^{1, a, *}$ \\ ${ }^{1}$ Faculty of Law, Xiamen University, South Siming Road, Xiamen, China \\ a email zealous007@sina.com \\ *corresponding author
}

Keywords: Refugee employment, Refugee settlement, Foreign investment policy-making.

\begin{abstract}
In recent years, the refugee settlement problem worse, raising global concern. The refugee problem, however, is difficult to be solved in the short term, which makes, including the United Nations, international organizations, world big powers, refugees, are very headache. Against such a backdrop, the refugee settlement problem is rooted in addressing poverty. Though it is not possible to forbid war immediately, we could try our best to solve the poverty problem. One step is to supply work for refugee immigrants. If a host country cannot supply enough work, refugee immigrants will face poverty, hunger, high crime rate and discrimination. At the same time, transnational companies face the staff shortage in the investment process of the host country. Moreover, the home countries of refugees are still in flames, apparently unable to provide the refugees with normal life needs. Therefore, if the host country can agree on some clause in international investment policy-making with transnational companies, it is possible to add the refugee factor into the performance requirements clause flexibly in the formulation of investment policies, thus alleviating the global governance impact from the refugee problem in a short time, but also reduce the workload of UNHCR and relieve the suffering of refugees resettlement.
\end{abstract}

\section{Introduction}

According to one sports news, it is reported that the International Olympic Committee (IOC) has set up the first Refugee Olympic Team among 207 participating nations in 2016 Rio Olympics, and this was the first time in the Olympics' history. More importantly, the IOC considered the move to introduce a first-ever refugee team as a symbol of hope. Although the refugee team didn't wear any 'identity', the ten refugee participants still have gained a lot of applause. It is said that refugee problems arise from ceaseless war and poverty. Though it is not possible to forbid war immediately, we could try our best to solve the poverty problem. One step is to supply work for refugee immigrants. If a host country cannot supply enough work, refugee immigrants will face poverty, hunger, high crime rate and discrimination. If a transnational company wants to invest in a host country, it really needs a large numbers of workers, obviously, it is impossible to employ all the workers from home country; and if the host country may demand the transnational company (TNC) to employ some qualified refugees under some circumstances, such as in host country foreign investment policy-making, perhaps some troubles among host country, transnational company and refugee immigrants will find their satisfied answers respectively.

\section{Concerns Need Be Focused}

Now, concerns about refugee problems need be focused from the following dimensions. How will host countries solve the problem of the refugee immigrants settlement? How will the transnational company solve the problem of employee shortage? And how will the refugee immigrants gain work and salary? The circumstances mentioned above will be discussed in my essay. More importantly, the author will focus whether it is possible to add some refugee employment element or clause into host country policy-making when a transnational company 
invests.

\subsection{The current Refugee problems}

The current refugee problems are manifested in the following aspects, refugee on settlement and resettlement matters, dilemma of host countries on refugee matters, and hard work of UNHCR on refugee matters.

\subsubsection{Refugee on Settlement and Resettlement Matters}

According to the UN Refugee Agency (UNHCR), Refugees are people fleeing conflict or persecution. They are defined and protected in international law, and must not be expelled or returned to situations where their life and freedom are at risk. At UNHCR, we have been assisting them for over half a century. According to statistics, the number of refugees rose to 19.9 million in 2017. About 2.7 million people were newly registered as refugees during 2017, double the amount from 2016 and close to the record number of new refugee arrivals registered in 2014.

First of all, every refugee in protection faces how to solve settlement dilemma. Even if the host country complies with international obligations and has internal legal regulations to accept refugees, that doesn't mean every refugee have right to enter that host country in fact. Refugees who have passed the host country refugee regulations are still faced with survival problems when they enter the host country. In order to survive, the refugees had to consider leaving their present host country and moving to another new country. Thus, the resettlement problem arises thereafter. Refugees will face death, hunger, unemployment, and discrimination before they reach the host country, even to be a crime victim or a criminal. Similar problems still exist after they arrive in the host country. For instance, according to one story from UN News Center, asylum seekers are reporting sexual harassment and violence at some sub-standard reception centres on Greek islands - where even bathing during the daytime can be dangerous - despite Government measures to address the dire living conditions, the United Nations refugee agency warned on Friday.

\subsubsection{Dilemma of Host Countries on Refugee Matters}

The host country has a dilemma about the attitude of refugees. The influx of refugees into the host country would be a waste of resources and a burden on the host country's social governance and was thus criticized by its nationals. However, the failure to accept refugees would also render the host country unable to assume international responsibility and trigger negative international public opinions.

In order to deal with the above difficulties, host countries are not willing to accept too many refugees, and the admittance of refugees will become more stringent and the examining and approving period will become longer.

\subsubsection{Hard Work of UNHCR on Refugee Matters}

As the Agency for the Protection of refugees, the United Nations refugee agency (UNHCR) has to repeatedly call on and urge different countries to achieve the purpose of protecting and assisting refugees around the world. However, things are slow, lack of financial support and a lack of strong supporters, UNHCR's work faces many challenges and unexpected situations.

The changes in the host country's legal policy, the change of social governance model and the trend of economic situation will all affect the UNHCR's refugee global settlement action. At the same time, the refugee resettlement problem will increase a workload of the UNHCR.

\subsection{TNCs Need More Labour}

According to UNHCR's report, developing regions hosted 85 percent of the world's refugees under UNHCR's mandate, about 16.9 million people. And the main countries of asylum for refugees were: Turkey, Pakistan, Uganda, Lebanon, Islamic Rep. of Iran, Germany, Bangladesh, Sudan. If one TNC wants to invest in countries above, such as Germany or Bangladesh, perhaps that TNC needs a larger number or lower price of labour, thereafter whether TNC could employ a qualified refugee in the host country? 
In Article 17 of the 1951 Refugee Convention, it stipulates wage-earning employment. It reads,

1. The Contracting State shall accord to refugees lawfully staying in their territory the most favourable treatment accorded to nationals of a foreign country in the same circumstances, as regards the right to engage in wage-earning employment.

2. In any case, restrictive measures imposed on aliens or the employment of aliens for the protection of the national labour market shall not be applied to a refugee who was already exempt from them at the date of entry into force of this Convention for the Contracting State concerned, or who fulfils one of the following conditions:

(a) He has completed three years' residence in the country;

(b) He has a spouse possessing the nationality of the country of residence. A refugee may not invoke the benefits of this provision if he has abandoned his spouse;

(c) He has one or more children possessing the nationality of the country of residence.

3. The Contracting States shall give sympathetic consideration to assimilating the rights of all refugees with regard to wage-earning employment to those of nationals, and in particular of those refugees who have entered their territory pursuant to programmes of labour recruitment or under immigration schemes.

Hence, freedom of work for refugees after they entered the host country is no longer a problem. The question is whether it is possible to add some refugee employment element or clause into host country policy-making when a transnational company invests.

As can be seen from the table below, the main countries for refugee asylum, except Germany, are foreign direct investment inflows.

Table 1 FDI and EXTERNAL FINANCIAL RESOURCES 2016

\begin{tabular}{|l|l|l|l|}
\hline No. & Country & FDI Inflows* & FDI outflows* \\
\hline 1 & Turkey & 11987.00 & 2869.00 \\
\hline 2 & Pakistan & 2006.00 & 52.00 \\
\hline 3 & Uganda & 541.19 & -- \\
\hline 4 & Lebanon & 2563.92 & 773.21 \\
\hline 5 & Islamic Rep. of Iran & 3372.00 & 104.11 \\
\hline 6 & Germany & 9528.28 & 34557.54 \\
\hline 7 & Bangladesh & 2332.72 & 40.53 \\
\hline 8 & Sudan & 1063.77 & -- \\
\hline$*$ Note: & millions of US\$ unless otherwise. \\
\hline
\end{tabular}

Therefore, it is necessary to distinguish between the FDI net inflow country and FDI net outflow country's different situation to discuss. And there is no need to discuss for the FDI net inflow and outflow balanced country, because it could take a compromise strategy in the corresponding investment policy. Hence, performance requirements of international investment agreement need be taken into consideration.

\subsubsection{For the FDI net inflow country as a host country}

For the FDI net inflow country, international investors need labor to run multinational companies. If the host country wished to address the issue of refugee employment, it might wish to consider signing a bit with an investor that included performance requirements, but performance requirements could be used as an elastic clause and not mandatory.

This performance requirement can be set to, if the investor employs a sufficient to meet the standards of the refugees, the host country can give certain preferential policies, such as tax relief. However, it is important to note that the refugee must be legally admitted to the host country and must meet the standards of employment. In that case, since the host country's adoption of such a policy would result in competition between refugees who were not nationals of their own country and their nationals in the job market, the expectation of remuneration could be lowered if refugees 
wished to make a living in the host country. So, on the basis of equal pay, how do we balance the interests of host countries, refugees, and multinational corporations?

Firstly, the host country has a certain limit on the number of refugees received each year, as requested by the UNHCR. In this way, the refugees can be trained in labour skills, thereby adopting a quota system, which would be recommended to multinational companies to meet the standards of employment. Secondly, given the profitability of multinational corporations and their enthusiasm for investing in the host country, on a voluntary basis by multinational corporations, the host country can offer preferential policies, such as tax incentives, or fast-track services in administrative approvals, to shorten the waiting time in the operation of multinational corporations. Thirdly, given the benefits of capital, the host country should not allow a multinational company to employ more refugees than a percentage of the total number of employees, unless it is necessary. This is to prevent transnational corporations from abusing preferential rights while preventing transnational corporations from taking refugees as slaves and violating the legitimate human rights of refugees.

\subsubsection{For the FDI net outflow country as a host country}

For the FDI net outflow country, it needs lots of labor services to national economy. In the case of a net outflow of capital from the host country, in the process of receiving refugees, the host country had a high labour cost and refugees could solve the problem of low-grade labor force in the host country. Thus, for transnational investors, in the FDI net outflow country, a moderate amount of hire refugees to labor standards will help reduce the cost of the enterprise. But, in general, international investors will consider personal danger to refugees and crime problem, so reluctant to hire refugees' employees. Under such circumstances, it is still necessary for the host Government to give preferential policies to transnational enterprises.

\section{Conclusion}

To sum up, it can be expanded explanations in performance requirements of international investment agreement, so that the host country's refugee employment factors are flexibly embedded in terms of BIT, for transnational investors freely choose whether to adopt the investment policy plan or not. For the multinational investors adopting the scheme, the host country can offer certain preferential on investment policy, such as tax concessions or expedite the administrative approval process, etc.

\section{References}

[1] http://www.unhcr.org/en-us/news/latest/2016/8/57a9794c4/live-blog-refugee-olympic-teamturns- dreams-reality-rio.html

[2] http://www.unhcr.org/en-us/refugees.html

[3] Global Trends. Forced Displacement in 2017. P.18.

[4] https://refugeesmigrants.un.org/women-and-children-threatened-sexual-violence-refugeereception-centres-greek-islands---un

[5] http://www.unhcr.org, Global trends 2017 p.2.

[6] Source: UNCTAD stat (http://unctadstat.unctad.org) 